\title{
Bile Salts, Sterols, Sterol Esters, Glycerides and Fatty Acids in Micellar and Oil Phases of Intestinal Contents during Fat Digestion in Man
}

\author{
By T. A. Miettinen and M. Siurala \\ Third Department of Medicine, and Gastroenterological Unit, Second Department of Medicine, \\ University of Helsinki, Finland
}

(Eingegangen am 10. August 1970)

\begin{abstract}
The relationship between intestinal bile acids and the micellar solubilization of lipids was studied by determining micellar bile acids and distribution of cholesterol and $\beta$-sitosterol, their esters, and of hydrolysis products of triglycerides (labeled with ${ }^{3} \mathrm{H}$-tristearate), free fatty acids, monoglycerides and diglycerides between the micellar and oil phases of the intestinal contents for $11 / 2 \mathrm{~h}$ after the administration of a fatty meal to normal human subjects. The dilution of radioactivity indicated that non-labeled lipids were sccreted during fat digestion into the gut lumen particularly into the micellar free fatty acids fraction. About one third of the total intestinal lipids was solubilized by the micellar phase, which consisted primarily of free fatty acids and monoglycerides while triglycerides and diglycerides were concentrated in the oil phase. Half of the total intestinal cholesterol and only one third of the $\beta$-sitosterol were in the micellar phase, primarily in the free form. Esterified sterols were enriched in the oil phase which also contained, compared to cholesterol, a relatively high amount of free $\beta$-sitosterol, suggesting that low micellar solubilization of this stetol is a factor in its low absorption. Calculations indicated that unabsorbable $\beta$-sitosterol could be used as an internal marker for lipid absorption. The levels of total micellar lipids and micellar $\beta$ sitosterol were not correlated with the micellar bile acid concentration, while the concentration of intestinal cholesterol showed a correlation with the bile acids or the molar sum of bile acids, monoglycerides and free fatty acids. The level of free, esterified and total micellar sitosterol was correlated with free fatty acids, total lipids and the molar sum of miccllar bile acids, monoglycerides and free fatty acids, indicating that the digestion products of triglycerides actually contribute to micellar solubilization of sterols.
\end{abstract}

Die Beziehungen zwischen Gallensäuren des Darminhaltes und der micellaren Lösung von Lipiden wurden bei gesunden Probanden untersucht durch Bestimmung der micellaren Gallensäuten, der Verteilung von Cholesterin, $\beta$-Sitosterin (und ihren Estern) und der Hydrolyseprodukte mit ${ }^{3} \mathrm{H}$-markierten Triglyceriden (freie Fettsäure, Monoglyceriden und Diglyceriden) zwischen der micellaren und Olphase 11/2 Stunde nach Verabreichung einer Fettmahlzeit. Die Verdünnung der Radioaktivität deutete auf eine Sekretion von nicht markierten Lipiden in das Darmlumen besonders in die micellare Fraktion der freien Fettsäuren. Etwa 1/3 der Gesamtlipide des Darminhaltes wurde von der micellaten Phase gelöst, die zum größten Teil aus freien Fettsäuren und Monoglyceriden bestand, während der Hauptteil der Triglyceride und Diglyceride in der Olphase konzentriert war. Die Hälfte des Gesamtcholesterins des Darmes und $1 / 3$ des $\beta$-Sitosterins befanden sich in der micellaren Phase, hauptsächlich in der-freien Form. Veresterte Sterine wurden angereichert in der Ölphase, die verglichen mit Cholesterin eine verhältnismäßig große Menge von freiem $\beta$-Sitosterin enthielt, was darauf hinweist, daß die schlechte micellare Lösung dieses Sterins eine der Ursachen ihrer schlechten Absorption ist.

Berechnungen ergaben, daß nicht absorbierbares $\beta$-Sitosterin als Markierungssubstanz für die Messung der Lipidabsorption benutzt werden kann. Der Gesamtinhalt an micellaren Lipiden und micellarem $\beta$-Sitosterin zeigte keine Korrelation zur micellaren Gallensäurekonzentration, während die Konzentration des Cholesterins im Darm eine Korrelation zu den Gallensäuren oder der Summe der molaren Konzentrationen von Gallensäuren, Monoglyceriden und freien Fettsäuren aufwies. Der Gehalt an freiem, verestertem und gesamtem micellaren Sitosterin zeigte eine Korrelation mit den freien Fettsäuren, Gesamtlipiden und der Summe der molaren Konzentrationen vonmicellaren Gallensäuren, Monoglyceriden und freien Fettsäuren, was darauf hinweist, daß die Verdauungsprodukte von Triglyceriden tatsächlich zur micellaren Lösung von Sterinen beitragen.

Cholesterol and the digestion products of glycerides are known to be partitioned between the micellar and oil phases in the intestinal contents $(1-3)$. The formation of the micellar phase with the aid of conjugated bile salts is considered to be important, although perhaps not essential, for the intestinal absorption of fats $(2-5)$. Cholesterol absorption requires bile salts $(6,7)$ and is improved by dietary glycerides (8-11), obviously because the free fatty acids and monoglycerides formed during fat digestion contribute to the micellat solubilization of cholesterol (12). Details of the partition of free fatty acids and lower glycerides between the oil and micellar phases in normal subjects have been presented in only one study (12). With regard to cholesterol and its esters, their distribution in the intestinal contents during fat absorption is still incompletely recorded and no information is available on their relationship to intestinal detergents, bile salts, free fatty acids and monoglycerides, in normal and pathological conditions, and, in this respect, nothing is known about the behaviour of unabsorbable $\beta$-sitosterol and its esters. In the present paper the relationship between bile salts and micellar solubilization of both cholesterol and $\beta$-sitosterol and their esters, and also of total lipids, free fatty acids and monoglycerides were studied during fat digestion in the intestinal contents of normal human subjects.

\section{Material and methods}

The study was performed on 12 patients without gastrointestinal or hepatic disorders. All the patients were hospitalized in ordinary wards and after an overnight fast they were intubated with a double-lumen tube (outer diameter $5 \mathrm{~mm}$ ), the distal tip of which was placed $5 \mathrm{~cm}$ aborally from the ligament of Treirz. The position of the tube was checked by nuoroscopy. 
Through one lumen of the tube $300 \mathrm{ml}$ of a liquid formula meal was infused into the stomach. The formula was prepared by mixing $176 \mathrm{~g}$ of olive oil and $200 \mathrm{~g}$ of skim milk powder, and made up to $3 l$ with water. Cholesterol palmitate (Merck), plant sterols ( $\beta$-sitosterol, Merck; contained, according to gas-liquid chromatography, $85 \%$ of $\beta$-sitosterol, and $15 \%$ of campesterol and stigmasterol) and ${ }^{3} \mathrm{H}$-tristearate (Amersham, Cambridge, England; purified by thin-layer chromatography before use) were dissolved in the added oil so that, according to gas-liquid chromatography analysis, the formula contained $240 \mu \mathrm{g} / \mathrm{ml}$ of cholesterol (235 $\mu \mathrm{g}$ of ester and $5 \mu \mathrm{g}$ of free cholesterol) and $453 \mu \mathrm{g} / \mathrm{ml}$ of $\beta$-sitosterol ( $430 \mu \mathrm{g}$ of free and $23 \mu \mathrm{g}$ of ester sitosterol), the specific radioactivity being 2500 decays per minute and $\mathrm{mg}$ of total lipids. The $\beta$-sitosterol was added to improve the accuracy of the analysis; since this sterol is known to be almost unabsorbable (13-15), it was considered to be a convenient marker of the intestinal absorption of fats. Ten minutes after the infusion, continuous suction of the intestinal contents was started via the other lumen (located at the tip of the tube) of the cannula with a vacuum pump (negative pressure $10 \mathrm{~cm}$ of water). Collection of intestinal fluid was carried out in periods of 5 min over $11 / 2 \mathrm{~h}$ into test tubes placed in a $70^{\circ} \mathrm{C}$ water bath for inactivation of lipase (3). In most cases, all the samples were pooled; in four cases the pooling was performed in periods of half an hour.

\section{Lipid analysis : i}

After an aliquot had been removed for total lipid and sterol analysis, the micellar and oil phases of the intestinal contents were separated by ultracentrifugation as proposed by HOFMANN and Borgströs (3), except that the centrifugation time was $2 \mathrm{~h}$. Aliquots of oil droplets (termed the oil phase), which separated into the top of the tube, and of infranatant (termed the micellar phase) were removed for lipid analysis. The lipids of the uncentrifuged aliquot and of the micellar phase as well as of the liquid formula were extracted, using a liquid-to-liquid extraction method (16), and determined gravimetrically. Aliquots of the extracted lipids were removed for measurement of total radioactivity, and for chemical analysis of total lipids, cholesterol and $\beta$-sitosterol. The rest of the samples were subjected to thin layer chromatography on silica gel G. The plate was developed with heptane: ethyl ether: acetic acid $(40: 10: 1 \mathrm{v} / \mathrm{v})$, after which sterol esters, triglycerides, free fatty acids, 1,3-diglycerides (including free sterols), 1,2-diglycerides and monoglycerides were recovered.

Cbolesterol and $\beta$-sitosterol were determined as their trimethyl silyl ethers by the gas-liquid chromatography method (17), samples containing esterified sterols being first saponified in alkaline ethanol. Triglycerides, lower glycerides and free fatty acids were determined with the carboxyl ester reaction (18). For this purpose total lipid samples and free fatty acid fractions were first methylated with $5 \% \mathrm{HCl}$-methanol.

Total lipids and sterols (free and esterified) of the oil phase were obtained by the difference between the values of the total intestinal contents and those of the micellar phase. Sterols possibly sedimented during centrifugation (12) are included in the oil-phase sterols. The proportions of ester and free sterols, as well as the distribution pattern of triglyceride and its digestion products in the oil and micellar phases were obtained by analysis of the thinlayer chromatography fractions. With the procedure employed, total lipids can be determined in three different ways; 1 . gravimetrically (cholesterol and $\beta$-sitosterol are subtracted), 2 . chemically and 3. isotopically. In the isotopic method the number of dpm in the total lipids or in each thin-layer chromatography fraction was divided by the specific activity of total fats in the liquid formula. Chemical and isotopic determination of total micellar lipids, and the amounts of total micellar sterols agreed well with the respective sums of triglycerides, free fatty acids, diglycerides and monoglycerides, and free and esterified sterols recovered from the thin-layer chromatography plate, indicating that no appreciable losses were incurred during the thin-layer chromatography procedure.

The micellar phase was also analyzed for free and total bile acids. The latter were determined by the method described for fecal bile acids (17), except that thin-layer chromatography purification of the extracted and methylated bile acids was omitted and that in five cases gas liquid chromatography analysis of trimethylsilyl derivatives was also carried out on a $1 \%$ NGS column to ascertain the amounts of the different bile acids. Bile acids possibly sedimented during centrifugation are not included. For free bile acids, $1 \mathrm{~m} l$ of the micellar phase was diluted with $1 \mathrm{~m} l$ of ethanol and acidified with one drop of conc. $\mathrm{HCl}$. After removal of sterols and other soluble lipids with petroleum ether, free bile acids were extracted three times with $5 \mathrm{ml}$ of ethyl ether. The extract was evaporated, bile acids methylated with methanol- $\mathrm{HCl}$ and analyzed as trimethylsilyl derivatives with gas-liquid chromatography on both $1 \%$ DC-560 and NGS columns, as in the case of total bile acids. The completeness of the extraction of free bile acids was checked with ${ }^{3} \mathrm{H}$-cholic acid added to the ethanolic solution at the beginning of the procedure.

\section{Results \\ Measurement of lipids in intestinal contents by different methods}

Table 1 shows that the gravimetric method records a higher value for total lipids in the intestinal contents than either the chemical or the isotope methods. In view of the relatively high chemical value for the micellar phase $(89 \%)$, the low isotope value for the micellar phase $(73 \%$ of the gravimetric value) and the relatively high one for the oil phase $(92 \%)$ suggest that during the process of digestion non-labeled lipids were secreted into the micellar phase, their contribution to the oil phase being negligible. This assumption is strengthened by the approximately identical pattern of lower glycerides and free fatty acids in the oil phase obtained from the thin-layer chromatography fractions by both the chemical and the isotopic methods. In the micellar phase, however, the relative amount of lower glycerides, particularly of monoglycerides, is higher and that of free fatty acids lower by the isotopic than by the chemical method. Thus, though the possibility exists that, as regards lipolysis and absorption, ${ }^{3} \mathrm{H}$-tristearate differs from olive oil, the appearance of additional non-labeled free fatty acids during digestion in the micellar phase could account for the relatively low total lipid value of the micellar phase obtained by the isotopic technique.

Tab. 1 Distribution of lipids between the micellar and oil phases of the intestinal contents during fat absorption in man, as determined by different
methods

\begin{tabular}{cccccccc}
\hline $\begin{array}{c}\text { Phase of } \\
\text { Intestinal Content }\end{array}$ & Assay Method & Total Lipids ${ }^{1}$ ) & Triglycerides ${ }^{2}$ ) & Free Fatty Acids & 1,3-diglycerides & 1,2-diglycerides & Monoglycerides \\
\hline Micellar & Chemical & $89 \pm 4$ & $2.6 \pm 2.0$ & $76.5 \pm 4.8$ & $1.7 \pm 0.4$ & $5.8 \pm 2.1$ & $13.5 \pm 0.2$ \\
Oil & Isotope & $73 \pm 3$ & $1.8 \pm 0.9$ & $68.4 \pm 6.8$ & $3.0 \pm 3.0$ & $5.8 \pm 1.8$ & $19.8 \pm 0.9$ \\
& Chemical & $89 \pm 3$ & $45.7 \pm 4.4$ & $22.8 \pm 2.3$ & $8.1 \pm 1.4$ & $20.4 \pm 2.1$ & $3.3 \pm 0.6$ \\
\hline
\end{tabular}

1) The amount of total lipids by weight was taken as 100 , and the values of the chemical and isotopic methods expressed in relation to this.

2) The values of triglycerides and their digestion products are percents of total lipids in each phase. 
Tab. 2

Distribution of triglycerides and digestion products between the micellar and oil phases of the intestinal contents after administration of a fatty meal to normal human subjects

\begin{tabular}{|c|c|c|c|c|c|c|c|c|c|c|c|c|c|}
\hline \multirow[b]{2}{*}{$\begin{array}{l}\text { Sub- } \\
\text { ject }\end{array}$} & \multirow[b]{2}{*}{$\begin{array}{l}\text { Tri- } \\
\text { glycer- } \\
\text { ides }\end{array}$} & \multicolumn{5}{|c|}{ Micellar phase, $\mu \mathrm{g} / \mathrm{ml}$} & \multirow[b]{2}{*}{$\begin{array}{l}\text { Tri- } \\
\text { glycer- } \\
\text { ides }\end{array}$} & \multicolumn{5}{|c|}{ Oil phase, $\mu \mathrm{g} / \mathrm{m} l$} & \multirow{2}{*}{$\begin{array}{c}\text { Total } \\
\text { lipids of } \\
\text { intestinal } \\
\text { contents }\end{array}$} \\
\hline & & $\begin{array}{l}\text { Free } \\
\text { fatty } \\
\text { acids }\end{array}$ & $\begin{array}{l}\text { 1,3-di- } \\
\text { glycer- } \\
\text { ides }\end{array}$ & $\begin{array}{l}\text { 1,2-di- } \\
\text { glycer- } \\
\text { ides }\end{array}$ & $\begin{array}{l}\text { Mono- } \\
\text { glycer- } \\
\text { ides }\end{array}$ & $\begin{array}{l}\text { Total } \\
\text { lipids }\end{array}$ & & $\begin{array}{l}\text { Free } \\
\text { fatty } \\
\text { acids }\end{array}$ & $\begin{array}{l}\text { 1,3-di- } \\
\text { glycer- } \\
\text { Ides }\end{array}$ & $\begin{array}{l}\text { 1,2-di- } \\
\text { glycer- } \\
\text { ides }\end{array}$ & $\begin{array}{l}\text { Mono- } \\
\text { glycer- } \\
\text { ides }\end{array}$ & $\begin{array}{l}\text { Total } \\
\text { lipids }\end{array}$ & \\
\hline $\begin{array}{r}1 \\
2 \\
3 \\
4 \\
5 \\
6 \\
7 \\
8 \\
9 \\
10 \\
11 \\
12\end{array}$ & $\begin{array}{l}22 \\
21 \\
33 \\
50 \\
38 \\
34 \\
17 \\
80 \\
34 \\
53 \\
70 \\
38\end{array}$ & $\begin{array}{l}1769 \\
1681 \\
2515 \\
5870 \\
5990 \\
1570 \\
1285 \\
2910 \\
1639 \\
1557 \\
2545 \\
8005\end{array}$ & $\begin{array}{r}44 \\
64 \\
33 \\
86 \\
120 \\
34 \\
36 \\
120 \\
22 \\
29 \\
67 \\
190\end{array}$ & $\begin{array}{r}44 \\
64 \\
99 \\
186 \\
376 \\
78 \\
136 \\
590 \\
238 \\
248 \\
90 \\
248\end{array}$ & $\begin{array}{r}332 \\
298 \\
629 \\
956 \\
992 \\
272 \\
644 \\
2020 \\
872 \\
761 \\
1337 \\
946\end{array}$ & $\begin{array}{l}2211 \\
2128 \\
3309 \\
7148 \\
7516 \\
1988 \\
2118 \\
5720 \\
2805 \\
2648 \\
4109 \\
9427\end{array}$ & $\begin{array}{r}578 \\
562 \\
1430 \\
8460 \\
5730 \\
5220 \\
10555 \\
10565 \\
7100 \\
6685 \\
1071 \\
3110\end{array}$ & $\begin{array}{l}2704 \\
3932 \\
1220 \\
4290 \\
4010 \\
1512 \\
2010 \\
3022 \\
1582 \\
1108 \\
1626 \\
1790\end{array}$ & $\begin{array}{r}222 \\
225 \\
70 \\
1900 \\
1110 \\
253 \\
321 \\
785 \\
206 \\
134 \\
261 \\
701\end{array}$ & $\begin{array}{r}756 \\
674 \\
628 \\
3430 \\
2645 \\
954 \\
1589 \\
4055 \\
1198 \\
912 \\
1042 \\
1419\end{array}$ & $\begin{array}{l}177 \\
168 \\
140 \\
579 \\
289 \\
228 \\
175 \\
670 \\
142 \\
107 \\
248 \\
143\end{array}$ & $\begin{array}{c}4437 \\
5561 \\
3488 \\
18659 \\
13784 \\
8167 \\
14650 \\
19097 \\
10228 \\
8946 \\
4248 \\
7163\end{array}$ & $\begin{array}{r}6648 \\
7689 \\
6797 \\
25807 \\
21300 \\
10155 \\
16768 \\
24817 \\
13033 \\
11594 \\
8357 \\
16590\end{array}$ \\
\hline$\mu \mathrm{g} / \mathrm{m} l$ & $41 \pm 6$ & $3111 \pm 643$ & $70 \pm 15$ & $200 \pm 46$ & $838 \pm 142$ & $4261 \pm 738$ & $\begin{array}{r}5089 \\
+1075\end{array}$ & $\begin{array}{r}2401 \\
\pm 333\end{array}$ & $516 \pm 155$ & $1609 \pm 330$ & $256 \pm 52$ & $\begin{array}{r}9870 \\
\pm 1586\end{array}$ & $\begin{array}{r}14130 \\
\pm 1990\end{array}$ \\
\hline $\begin{array}{l}\% \text { of } \\
\text { total }\end{array}$ & $1.0 \pm 0.1$ & $73.0 \pm 3.4$ & $1.6 \pm 0.2$ & $4.7 \pm 0.9$ & $19.7 \pm 2.7$ & $\begin{array}{l}31.1 \\
\left. \pm 4.1^{2}\right)\end{array}$ & $51.5 \pm 6.3$ & $24.4 \pm 5.5$ & $5.2 \pm 0.9$ & $16.3 \pm 1.5$ & $2.6 \pm 0.4$ & $\begin{array}{l}68.9 \\
\left. \pm 4.1^{1}\right)\end{array}$ & 100.0 \\
\hline
\end{tabular}

Total lipids were determined gravimetrically (values of cholesterol and plant sterols are subtracted) and distribution of digestion products by means of radioactivity (See Material and Methods).

1) Percent of total lipids in the intestinal contents.

Tab. 3

Composition of sterols in the test meal and distribution of cholesterol and $\beta$-sitosterol in the micellar and oil phases of the intestinal contents after administration of this test meal to normal subjects



Statistically significant differences $(P<0.05)$ between cholesterol and $\beta$-sitosterol are indicated by $\left.{ }^{1}\right)$, between the micellar and oil phases by $\left.{ }^{2}\right)$, and between the free and ester forms by $\left.{ }^{3}\right)$. Mean $\pm S E$ of twelve subjects.

In spite of the apparent differences between the various methods, the gravimetric technique was used routinely for the measurement of total lipids (cholesterol and plant sterols are subtracted from the values), while radioactivity was employed for the determination of the pattern of digestion products.

\section{Distribution of lipids between the micellar and oil phases of the intestinal contents}

Table 2 demonștrates that during the test period of $11 / 2 \mathrm{~h}$ after administration of $17.6 \mathrm{~g}$ fat as water-milk powder emulsion to normal subjects $30 \%$ (average $4.26 \mathrm{mg} / \mathrm{ml}$, range 1.98 to $9.43 \mathrm{mg}$ ) of lipids (sterols excluded) are solubilized into the micellar phase of the intestinal contents, the other $70 \%$ (average $9.87 \mathrm{mg} / \mathrm{ml}$, range 4.25 to $19.10 \mathrm{mg}$ ) remaining in the oil phase. Analyses carried out at half-hour intervals showed some variation from one period to another but the micellar lipid values of the first period (probably exposed to concentrated gall bladder bile) were not consistently higher than those of the second or third. Therefore, analyses were carried out for each patient on the pooled samples collected during $11 / 2 \mathrm{~h}$.

The bulk of the micellar lipids were due to free fatty acids (70\% of total) and monoglycerides (20\%). In the oil phase half of the lipids were intact triglycerides, one fourth free fatty acids and one fifth diglycerides (primarily 1,2-diglycerides), while the amount of mono- glycerides was negligible. In terms of absolute amounts, nonpolar triglycerides and both diglycerides are seen to be enriched in the oil phase, while monoglycerides are found primarily in the micellar phase and free fatty acids are partitioned equally between the two phases.

\section{Distribution of cbolesterol and plant sterols between micellar} and oil phases

The results are presented in Table 3. Half (54\%) of the total intestinal cholesterol was found in the micellar phase, primarily in free form ( $91 \%$ free and $9 \%$ esterified) while almost half of the cholesterol in the oil phase was esterified. The absolute amount of esterified cholesterol was enriched almost 5-fold in the oil phase, the amount of free cholesterol being 2-fold higher in the micellar than in the oil phase.

As compared to cholesterol, relatively less $\beta$-sitosterol was partitioned in the micellar phase $(34 \%)$ of the intestinal contents, the proportion in the oil phase being correspondingly higher $(66 \%)$. The percentage esterification of cholesterol and $\beta$-sitosterol was the same in the micellar phase, but in the oil phase significantly lower for $\beta$-sitosterol. Table 3 indicates that this might be due to the composition of the test meal which contains primarily esterified cholesterol and free $\beta$-sitosterol. However, the percentage esterification of $\beta$-sitosterol is higher both in the oil and micellar phases than in the test meal, indicating that some esterification 
might have occurred or free $\beta$-sitosterol disappeared. The absolute amount of esterified $\beta$-sitosterol, like cholesterol, was markedly higher (6-fold) in the oil phase than in the micellar phase, free $\beta$-sitosterol tending, in contrast to cholesterol, to be enriched in the oil phase also.

Assuming that no $\beta$-sitosterol was absorbed and that it was not secreted into the gut lumen, the volume of the pool by which the administered $\beta$-sitosterol was diluted could be calculated from the data of Table 3 and was found to be $850 \mathrm{ml}$. It contained $426 \mathrm{mg}$ of cholesterol, indicating that endogenous cholesterol was secreted into the pool, because the test meal contained only $72 \mathrm{mg}$ of cholesterol. The recovery of esterified cholesterol $(94 \mathrm{mg})$ and $\beta$-sitosterol $(29 \mathrm{mg})$ was higher than that administered (71 $\mathrm{mg}$ and $7 \mathrm{mg}$, respectively), suggesting that some esterification of both sterols had actually taken place. According to the data of Table 2, this pool contained $12 \mathrm{~g}$ of total lipids, a value which is $5.6 \mathrm{~g}$ lower than that originally administered to the patients. Since, according to the isotopic data, some endogenous lipids were secreted into the intestinal lumen, it could be concluded that by using $\beta$-sitosterol as a marker about one third of lipids was absorbed during the test period. Thus, $\beta$-sitosterol appears to be suitable as an internal marker of intestinal absorption.

\section{Intestinal bile acids}

Table 4 shows that less than $1 \%$ of the total intestinal bile acids are in free form. The total bile acid concentration averaged $2.5 \mathrm{mg} / \mathrm{l}$ or $6 \mathrm{~mm}$, which is clearly above the critical micellar concentration needed for the formation of the micellar phase. The lowest concentration of $1.6 \mathrm{mg}(4 \mathrm{~mm})$ was still associated with a marked micellar solubilization of both total lipids and sterols.

Tab. 4

Bile salt concentrations in the micellar phase of intestinal contents of normal subjects

\begin{tabular}{lcccc}
\hline Bile Acids & $\left.\mu \mathrm{g} / \mathrm{ml}^{2}\right)$ & \multicolumn{2}{c}{ Relative } & $\begin{array}{c}\text { Distribution, \%1) } \\
\text { Cholic } \\
\text { Acid } \\
\text { Desoxy- } \\
\text { Cholic } \\
\text { Chenodes- } \\
\text { oxycholic } \\
\text { Acid }\end{array}$ \\
\hline Total & $2997 \pm 525$ & $54 \pm 12$ & $15 \pm 6$ & $32 \pm 7$ \\
Free & $12 \pm 4$ & $45 \pm 14$ & $15 \pm 8$ & $40 \pm 9$ \\
\hline
\end{tabular}

1) Determined on 5 subjects

2) Determined on 12 subjects

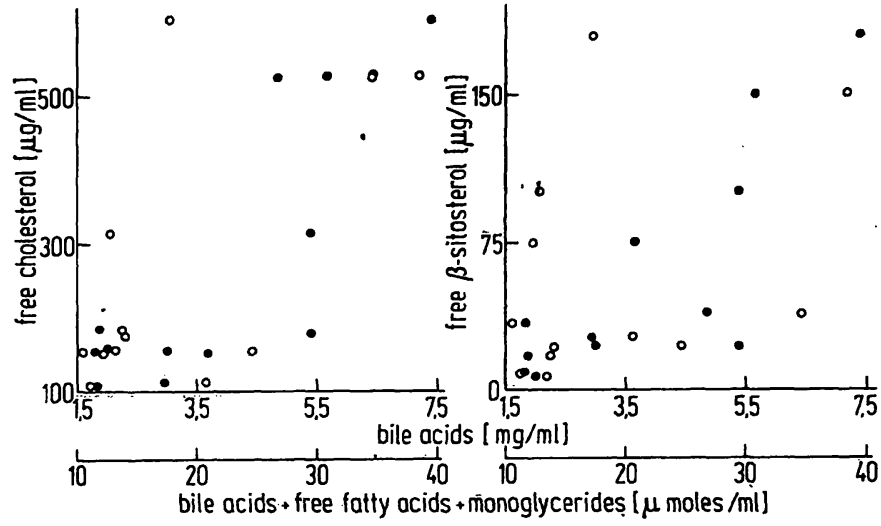

Fig. 1

Correlation of micellar free cholesterol (left panel ro $=0,64 ; \mathrm{r}$. $=0,80$ ) and $\beta$-sitosterol (right panel $\mathrm{ro}_{0}=0,30 ; \mathrm{r} \cdot=0,90$ ) with micellar bile acids (o) or the molar sum of micellar bile acids, free fatty acids and monoglycerides ( $(\bullet)$ in the intestinal contents of
normal human subjects during fat digestion

\section{Relationship between bile acids, sterols and total lipids}

Table 5 indicates that micellar total lipids, their major subfractions, free fatty acids and monoglycerides, and free, esterified and total $\beta$-sitosterol are not, while micellar free and total cholesterol are, dependent on the bile acid concentration of the intestinal contents in normal man. Micellar monoglycerides were not significantly correlated with any of the sterol fractions, but free fatty acids, total lipids, and the sum of monoglycerides and free fatty acids, were associated with micellar $\beta$-sitosterol. Finally, the sum of the molar concentrations of the bile acids, monoglycerides and free fatty acids, the three components which have been considered to be the major intestinal detergents (in addition to lecithin and/or lysolecithin) for micellar solubilization of non-polar solutes $(2,4)$, showed a highly significant correlation with all sterol fractions except cholesterol esters.

\section{Discussion}

Tristearate, a saturated long-chain glyceride, which was used in the present study to label the olive oil of the test meal, is probably digested somewhat more slowly by the pancreatic lipase than the majority of the triglyceride molecules of olive oil, which contains both short-chain and some unsaturated fatty acids. The isotope was not enriched in the oil phase, however, which suggests the same degree of lipolysis of tristearate and olive oil, the

Tab. 5

$1 \quad$ Correlation between various lipid fractions of the micellar phase during fat digestion and absorption in man

\begin{tabular}{|c|c|c|c|c|c|c|c|c|c|}
\hline $\begin{array}{l}\text { Intestinal } \\
\text { detergents }\end{array}$ & $\begin{array}{l}\text { Total } \\
\text { lipids }\end{array}$ & $\begin{array}{l}\text { Mono- } \\
\text { glycerides }\end{array}$ & $\begin{array}{l}\text { Free fatty } \\
\text { acids }\end{array}$ & Free & $\begin{array}{l}\text { elation coeff } \\
\text { Cholesterol } \\
\text { Ester }\end{array}$ & Total & Free & $\underset{\text { Ester }}{\beta \text {-sitosterol }}$ & Total \\
\hline $\begin{array}{l}\text { Total bile acids } \\
\text { Monoglycerides } \\
\text { Free fatty acids } \\
\text { Total lipids } \\
\text { Monoglycerides } \\
\text { + free fatty acids }\end{array}$ & -0.11 & -0.28 & -0.12 & $\begin{array}{ll} & 0.64 *) \\
0.18 \\
0.53 \\
0.50 \\
0.52\end{array}$ & $\begin{array}{r}-0.06 \\
-0.30 \\
0.37 \\
0.25 \\
0.28\end{array}$ & $\begin{array}{l}0.64 *) \\
0.16 \\
0.54 \\
0.51 \\
0.53\end{array}$ & $\begin{array}{l}0.30 \\
0.55 \\
\left.0.64^{*}\right) \\
\left.0.70^{*}\right) \\
\left.0.70^{*}\right)\end{array}$ & $\begin{array}{c}-0.05 \\
0.25 \\
\left.0.76^{*}\right) \\
\left.0.73^{*}\right) \\
\left.0.75^{*}\right)\end{array}$ & $\begin{array}{l}0.30 \\
0.55 \\
0.69 *) \\
0.74 *) \\
0.74 *)\end{array}$ \\
\hline $\begin{array}{l}\text { Bile acids }+ \text { mono- } \\
\text { glycerides }+ \text { free } \\
\text { fatty acids }\end{array}$ & & & & $0.80 *)$ & 0.24 & $0.81 *)$ & $\begin{array}{r}0.90 *) \\
;\end{array}$ & $0.67 *)$ & $0.87 *)$ \\
\hline
\end{tabular}

Statistically significant values $(P<0.05)$ are indicated by*). 
detected dilution of the isotope in the micellar phase being due either to the secretion of non-labeled lipids into the intestinal contents or to the more rapid transfer of the digestion products of ${ }^{3} \mathrm{H}$-stearate into the mucosal cells than those of olive oil. Quantitative thin-layer chromatography fractionation of micellar lipids indicated that the dilution was primarily due to free fatty acids, which could have been released, at least partly, by hydrolysis of phospholipids excreted with the bile into the intestinal lumen. Intestinal phospholipids are chiefly in the lysolecithin fraction formed by the action of a pancreatic lecithinase A on the bile lecithin (19).

The distribution of total lipids and digestion products of triglycerides between the oil and micellar phases of the intestinal contents found in the present study agreed well with the results presented by HoFMANN and BorgSTRÖM (3). Some minor differences were observed, however. Thus, the amount of monoglycerides (both absolute and relative) determined from the oil droplets of the oil phase was always markedly lower than in the micellar phase, while the amount of intact triglyceride molecules was relatively high in the oil phase. Moreover, thin-layer chromatogrpahy, radioactivity and chemical analysis indicated the presence of 1,3-diglycerides in both the oil and the micellar phases, the amount being, however, markedly lower than of 1,2-diglycerides. These differences may be primarily due to the use of relatively saturated olive oil and saturated tristearate in the present study in place of the highly unsaturated corn oil used by HOFMANN and BORGSTRÖM.

In vitro studies have shown that cholesterol esters enter the micellar phase to a lesser extent than does free cholesterol (20). This was seen under the in vivo conditions of the present study not only for cholesterol but also for $\beta$-sitosterol. The absolute amounts of the two sterol esters were, when total $\beta$-sitosterol was used as a marker, higher than those administered in the test meal so that some esterification of both sterols had occurred, this being relatively higher for $\beta$-sitosterol than for cholesterol. Pancreatic cholesterol esterase is actually able to synthesize sterol esters (cf. 21) though conditions in the intestinal lumen may favor hydrolysis rather than esterification (22-24).

Micellat solubilization of cholesterol in vitro is independent of whether cholesterol is added in the oil or micellar form (20). Yet it should be borne in mind that excretion of free cholesterol as bile salt-lecithin micelles via the bile into the intestinal lumen may have favored micellar solubilization of free cholesterol as compared to $\beta$-sitosterol which was administered in the oil. Endogenous and exogenous cholesterol are, however, evenly distributed between the micellar and oil phases of the intestinal contents in man (1). Though the mode of administration, the different absolute amounts of the two sterols (cholesterol is known to reduce micellar solubilization of $\beta$-sitosterol in vitro; 20 ) and possible intraluminal esterification may explain why the relative amount of $\beta$-sitosterol, remaining in the oil phase, was clearly higher than that of cholesterol, the possibility exists that the difference is due to the structural difference (the presence of an ethyl group in the side chain of $\beta$-sitosterol) betwcen the two sterols. In in vitro studies $\beta$-sitosterol, which is an almost unabsorbable sterol $(13,14)$, is partitioned in the same proportions as cholesterol (26) or to a lesser extent in the micellar phase $(20,25)$. The difference found here in the micellar solubilization in vivo as compared to cholesterol was so significant that it could markedly contribute to the difference in the intestinal absorption of the two sterols.

The results of the present study suggest that $\beta$-sitosterol could be used analogously to polyethylenglycol, as an internal unabsorbable marker for the studies of intestinal absorption. From the $\beta$-sitosterol values in the intestinal contents it was calculated that the $300-\mathrm{m} l$ test meal was diluted by about a factor of 3 during its passage through the duodenum. This is in a fairly good agreement with the polyethylenglycol experiments, which have indicated 3 - to 5 -fold dilution (27). The use of $\beta$-sitosterol as the reference compound provides that it is not absorbed or secreted into the gut lumen. That $\beta$-sitosterol is absorbed by experimental animals and human subjects has been demonstrated by many studies $(13-15,28-33)$, the daily absorption in man being only a few milligrams (15). Isolated intestinal segments or everted intestinal sacs of the rat take up cholesterol and plant sterols in the proportions in which these are present in the medium, while after oral administration of the sterol mixture the amount of $\beta$-sitosterol recovered from the intestinal mucosa or found in the chyle is relatively low (34). Perfusion studies with human intestinal segments in vivo have shown that the segment secretes a small amount of plant sterols into the gut lumen during at least two consecutive days after the last plant sterolcontaining meal (12). Thus, it is quite probable that a small amount of absorbed $\beta$-sitosterol is balanced by the corresponding secretion so that no actual intestinal loss or enrichment takes place.

The micellar lipid concentration has been demonstrated to bear a fair correlation with the bile salt concentration in the intestinal contents of normal man (35), an observation which was not confirmed in the present study, probably because the test meal was different. In our preliminary studies $(36,37)$ on patients with malabsorption, cirrhosis of the liver and ileal dysfunction, a significant correlation was found, however, between bile salts, and total lipids, cholesterol and $\beta$-sitosterol of the micellar phase.

The amount of micellar lipids in vivo depends not only on the rate of micellar solubilization (determined by the availability of digestion products and detergents, and by intestinal motility to allow a proper mixing) but also on the removal of solubilized lipids by absorption. Thus, a high ratc of absorption could lead to a low micellar lipid concentration even in the presence of high bile salt and solute concentrations. That the bile salts are not the only factor determining the micellar solubilization of lipids, particularly non-polar cholesterol, in the form of mixed micelles, has been demonstrated both in vitro 
$(2,4,5)$ and in perfusion studies in vivo (12). Thus, removal of free fatty acids and monoglycerides from the perfusion medium by absorption markedly reduced micellar solubilization of cholesterol, even though the bile salt concentration remained sufficiently high (12). Correlation of micellar cholesterol and $\beta$-sitosterol with the sum of free fatty acids, monoglycerides and bile acids and lack of correlation between $\beta$-sitosterol and bile acids alone gives additional evidence of the im- portance of digestion products in the solubilization of at least exogenous sterols into mixed micelles of intestinal contents during fat digestion and absorption in man.

\section{Acknowledgements}

The study is supported by grants from the State Medical Research Council of Finland and Sigrid Jusélius Foundation, and performed partly under a contract with the Association of Finnish life Assurance Companies.

\section{References}

1. BorgströM, B., J. Clin. Invest., 39, 809 (1960). - 2. HofmanN, A. F. and B. Borgström, Fed. Proc., 21, 43 (1962). - 3. HofmanN, A. F. and B. Borgström, J. Clin. Invest., 43, 247 (1964). - 4. HofMANN, A.F. and D. M. SMALl, Ann. Rev.Med., 18, 333 (1967). - 5. Johnston, J. M., in Handbook of Physiology, p. 1353, T. H. Wilson (ed.) Sec. 6. Vol. III. Williams and Wilkins, Baltimore (1968) - 6. Siperstein, M. D., I. L. Chaikoff and W. O. Reinhardt, J. biol. Chemistry, 198, 111 (1952). - 7. Vahony, G. V. and C. R. Treadwell, Amer. J. Physiol., 191, 179 (1957). - 8. Lorzides, P. A., Biochem. J., 32, 1345 (1938). - 9. KIM, K. S. and A. C. IVY, Amer. J. Physiol., 171, 302 (1952). - 10. PrhL, A., Acta Physiol. Scand., 34, 183 (1955). - 11. Swell, L., D. F. Flick, H. J. Field, jr. and C. R. Treadwell, Amer. J. Physiol., 180, 124 (1955). - 12. Simmonds, W. J., A. F. Hofmann and E. TheoDOR, J. Clin. Invest., 46, 874 (1967). - 13. GouLd, R. G., Trans, N. Y., Acad. Sci., 34, 183 (1955). - 14. Gound, R. G., R. J. Jones, G. V. LeRoy, R. W. Wissler and C. B. Taylor, Metabolism, 18, 652 (1969). - 15. SALEN, G., E. H. Ahrens, jr., and S. M. GRUNDY, J. Clin. Invest., 49, 952 (1970). - 16. BLANKENHORN, D. H. and E. H. Ahrens, jr., J. biol. Chemistry 212, 69 (1955). 17. Mifettinen, T. A., E. H. Ahrens, jr. and S. M. Grundy, J. Lipid Res., 6, 411 (1965). - 18. Grundy, S. M., E. H. Ahrens, jr. and T. A. Miettinen, J. Lipid Res., 6, 397 (1965). - 19. Borgström, B., Acta Chem. Scand., 11, 749 (1957). - 20. Feld-
MAN and B. BorgströM, Biochim. biophysical Acta, 125, 136 (1966). - 21. Goodman, D., Physiol. Rev. Baltimore, 45, 747 (1965). - 22. Favarger, P. and E. F. Metzger, Helv. chim. Acta, 35, 1811 (1952). - 23. Prirl, A., Acta Physiol. Scand., 34, 197 (1955). - 24. Swell, L. H., H. Field, jr. and C. R. Treadwell Proc. Soc. exper. Biol. Med., 103, 263 (1960). - 25. Barton, P. G. and J. Glover, In The biliary system. p. 189, W. Taylor, (ed.), Blackwell Scientific Publications, Oxford, (1965). - 26. BORGSTRÖM, B., J. Lipid Res., 8, 598 (1967). - 27. Borgström, B., A. DarLQvist, G. LundH and J. SjövalL, J. Clin. Invest., 36, 1521 (1957). 28. Swell, L., E. C. Trout, jr., H. Field, jr. and C. R. TreadweLL, J. biol. Chemistry, 234, 2286 (1959). - 29. Kuksrs, A. and T. C. Huang, Canad. J. Biochem., 40, 1493 (1962), - 30. FeldMAN, E. B. and B. Borgström, Biochim. biophysica Acta, Amsterdam, 125, 148 (1966). - 31. Mretrinen, T. A., Acta Chem. Scand, 21, 286 (1967). - 32. Blomstrand, R. and J. Gürtler, Arkiv för Kemi, 30, 233 (1968). - 33. Mretrinen, T. A. and T. LuUKkainen, Acta Chem. Scand., 22, 2603 (1968). - 34. Borgström, B., J. Lipid Res., 9, 473 (1968). - 35. VAN DeEst, B. W., J. S. Fordtran, S. G. Morawski and J. D. Wilson, J. Clin. Invest., 47, 1314 (1968). - 36. Mietrinen, T. A. and M. Siurala, Scand. J. Clin. Laborat. Invest., 19, Suppl. 95, 69 (1967). (Abstract). 37. Usenius, R. and T. A. Mretíinen, Scand. J. Clin. Laborat. Invest., 21, Suppl. 101, 78 (1968). (Abstract).

\section{Mailing adress: \\ Tatu Miettinen \\ Third Department of Medicine University of Helsinki Helsinki 29, Finland}




\section{Im Zeichen des Einhorrns}

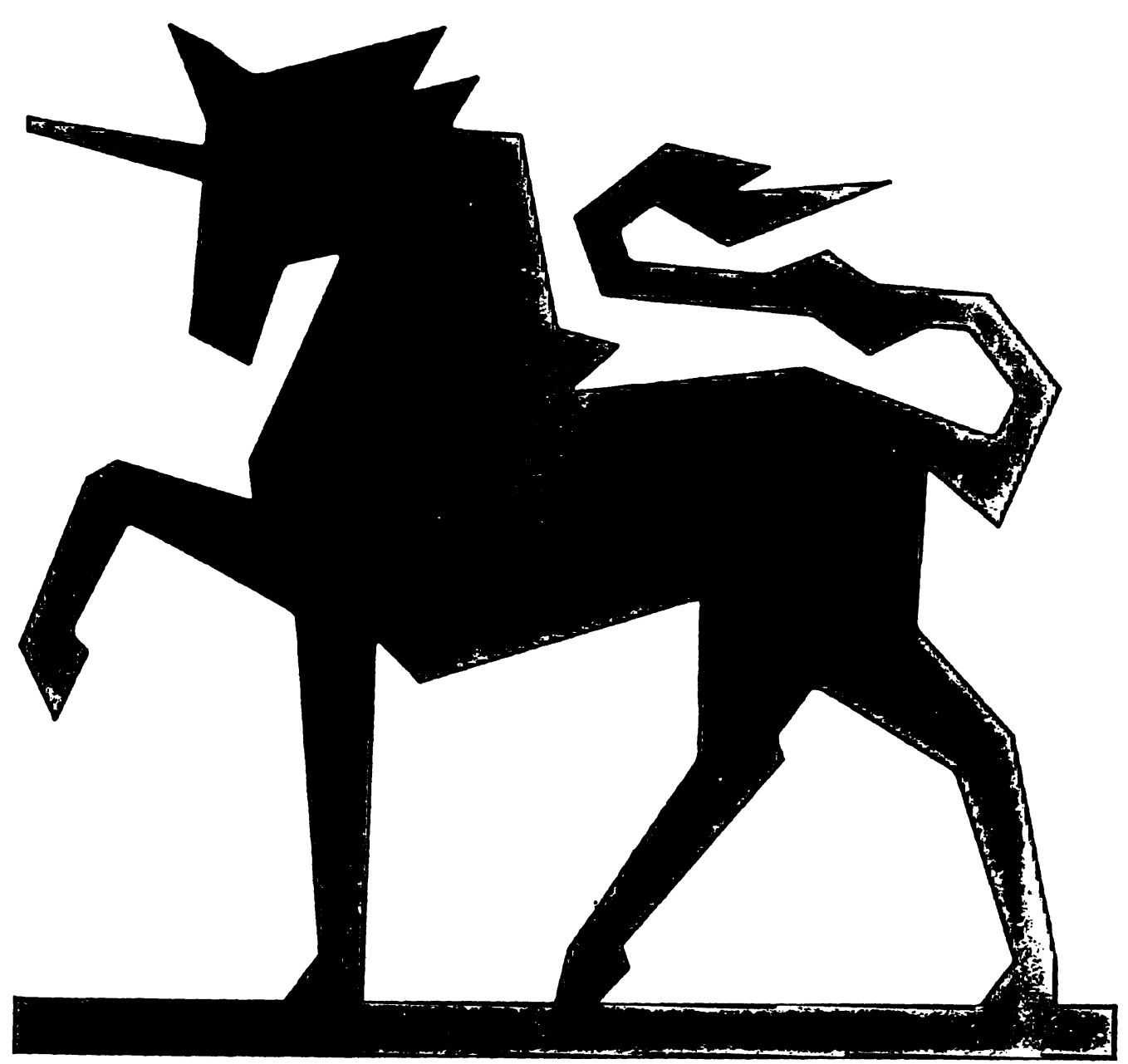

Wellcome Reagenzi:en

Qualitătsprodukte.

für das serologische

und bakteriologische

Laboratorium.

Hersteller:

Vertrieb

für die Bundesrepublik:

Wellcome Reagents Ltd.

Wellcome Research Laboratories England 


\section{Direkte \\ Kopplung von \\ Gas-Chromatographie und Dünnschicht- Chromatographie}

\section{mit CAMAG DIOCHROM}

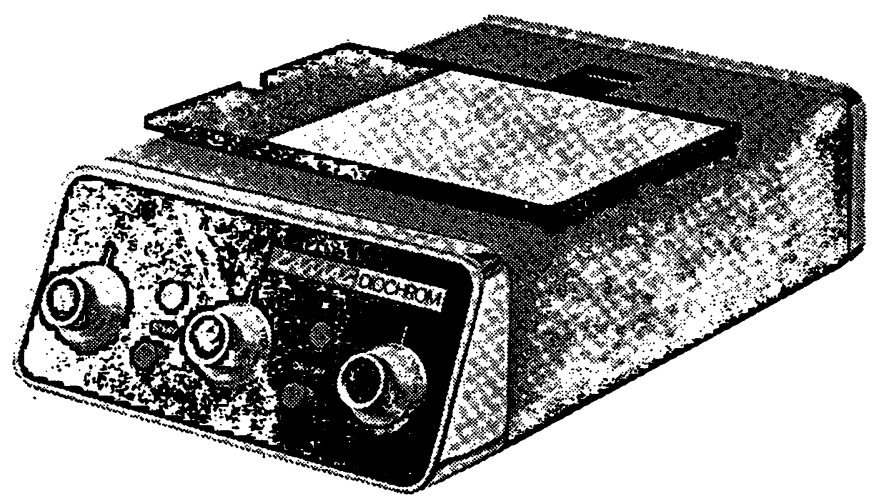

Mit dem CAMAG DIOCHROM sammeln Sie die Fraktionen des Gas-Chromatographen auf einer DC-Platte.

Der Plattenvorschub wird so programmiert, dass die Zuordnung von DC-Fraktion und GC-Peak immer einwandfrei möglich ist.

Damit haben Sie eine zuverlässige qualitative Identifizierung ohne Veränderung des GC-Systems.

Verlangen Sie unser ausführliches Angebot.

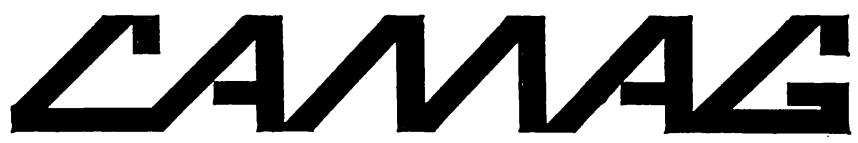

Homburgerstrasse 24 4132 Muttenz/Schweiz

Unser Zweigbetrieb in der Bundesrepublik:

1 Berlin 45, Baseler Strasse 65

Führend in Dünnschicht-Chromatographie Dünnschicht-Elektrophorese TL49 Hochspannungs-Elektrophorese
Asmus

\section{Einführung}

in die Höhere Mathematik und ihre Anw,endungen

Ein Hilfsbuch für Chemiker, Physiker und andere Naturwissenschaftler

Von Prof. Dr. ERIK Asmus

5. Auflage. Oktav. Mit 184 Abbildungen.

XII, 410 Seiten. 1969. Plastik flexibel DM 24,-

Wir wollen mit ganz besonderem Nachdruck darauf hinweisen, daß hier ein Buch vorliegt, das so sehr in der Sprache des Naturwissenschaftlers geschrieben wird, $\mathrm{da} ß$ es für den Biologen, Chemiker oder Physiker in ganz besonderem Maße lesbar wird. Vom Stoff her vermittelt das Buch ausführlich und an Hand sehr vieler Beispiele aus der Praxis des Naturforschers die Differentialrechnung und die Integralrechnung.

Die Natur, Stuttgart

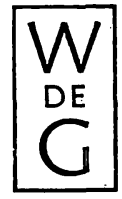

\section{Walter de Gruyter Berlin - New York}

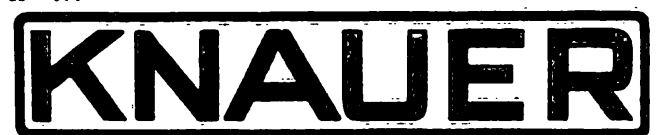

E LE KTRON IS CHES HALBMIKRO-OSMOMETER

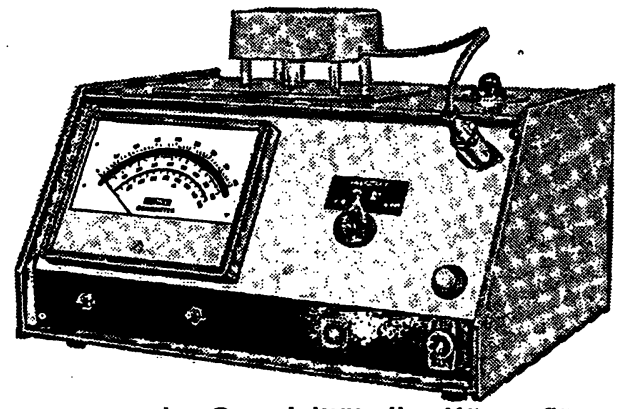

zur direkten Bestimmung der Osmolalität aller-Körperflüssigkeiten wie Blut, Serum, Urin, Liquor durch Gefrierpunktmessung.

Kontrolle der Nierenfunktion

Kontrolle von iso-, hyper- und hypotonischen Lösungen Prüfung von Infusionslösungen

- Probevolumen nur $0,15 \mathrm{ml}$ oder $0,05 \mathrm{ml}$

- Betriebsbereitschaft sofort nach dem Einschalten

- Dauer einer Messung ca. 2 Minuten.

- Meßgenauigkeit 1-2 Milliosmol/kg bzw. $1 \%$

- Preis DM 3600, - + MWSt

- Lieferung ab Lager oder laufenden Serien

Weitere Spezialität: Komplettes System zur Molekulargewichtsbestimmung zwischen 100 und 1000000 durch Kryoskopie, Dampidruck-Osmometrie und Membran-Osmometrie.

Wissenschaftlicher Gerätebau

KG Dr.-Ing. Herbert Knauer \& Co. GmbH,

1 Berlin 37 (West), Holstweg 18, Tel. (0311) 848705 